\title{
An Evaluation of the Environmental Payback Times and Economic Convenience in an Energy Requalification of a School
}

\author{
Francesco Asdrubali ${ }^{1, *}$, Daniela Venanzi ${ }^{2}{ }^{(0}$, Luca Evangelisti ${ }^{1}$, Claudia Guattari ${ }^{1}$, Gianluca Grazieschi ${ }^{1}{ }^{(1)}$, \\ Paolo Matteucci ${ }^{2}$ and Marta Roncone ${ }^{1}$ \\ 1 Department of Engineering, Roma Tre University, Via Vito Volterra 62, 00146 Rome, Italy; \\ luca.evangelisti@uniroma3.it (L.E.); claudia.guattari@uniroma3.it (C.G.); \\ gianluca.grazieschi@uniroma3.it (G.G.); marta.roncone@uniroma3.it (M.R.) \\ 2 Department of Economics, Roma Tre University, Via Silvio D'Amico 77, 00145 Rome, Italy; \\ daniela.venanzi@uniroma3.it (D.V.); paolo.matteucci@uniroma3.it (P.M.) \\ * Correspondence: francesco.asdrubali@uniroma3.it
}

Citation: Asdrubali, F.; Venanzi, D. Evangelisti, L.; Guattari, C.;

Grazieschi, G.; Matteucci, P.; Roncone,

M. An Evaluation of the Environmental Payback Times and Economic Convenience in an Energy Requalification of a School. Buildings 2021, 11, 12. https://doi.org/ $10.3390 /$ buildings11010012

Received: 4 November 2020 Accepted: 21 December 2020 Published: 28 December 2020

Publisher's Note: MDPI stays neutral with regard to jurisdictional claims in published maps and institutional affiliations.

Copyright: () 2020 by the authors. Licensee MDPI, Basel, Switzerland. This article is an open access article distributed under the terms and conditions of the Creative Commons Attribution (CC BY) license (https: / / creativecommons.org/ licenses/by/4.0/).
Abstract: The majority of Italian schools (70\%) were built in the absence of any legislation related to energy efficiency, and therefore have very low energy performance due to aging or poor quality of construction. An energy retrofit of this building stock is needed to meet the current European goals on greenhouse gas emission reduction. The retrofit is also needed in order to guarantee adequate comfort levels in indoor spaces and good conditions for learning and educational activities, that are often not reached in poor quality constructions. This work presents the results of an interdisciplinary study related to the energy requalification of a school located in Ostia, near Rome in Italy, built in the 1960s with a steel structure and Eternit infill. The scope of the analysis is to verify the economic and environmental effectiveness of four proposed retrofit interventions concerning the replacement of fixtures and the installation of an insulating coat. The current thermal transmittance of the walls was evaluated through thermofluximetric measurements conducted in situ; dynamic simulations were performed to determine the current energy performance and the energy performances following the four proposed retrofit scenarios. Energy and carbon payback times were evaluated (by means of the life cycle analysis (LCA) approach) and the economic value was determined for each of the four proposed retrofits, using a probabilistic approach. The results show that the replacement of windows is the most convenient intervention from all points of view. The study provides evidence that an assessment of schools' energy retrofits should include both economic and life cycle aspects.

Keywords: energy retrofit; economic analysis; net present value; capital asset pricing model; LCA; energy payback time; carbon payback time

\section{Introduction}

The construction sector is responsible for around $40 \%$ of final energy consumption and $36 \%$ of greenhouse gas emissions in Europe. Public buildings represent an important opportunity to promote energy efficiency and reduce consumption and climate-altering emissions. The Energy Performance Buildings Directive [1] has also imposed the Nearly Zero Energy Building Standard (almost zero energy buildings) for all new public buildings since 2019, giving public utility buildings an exemplary role in terms of energy efficiency and renewable sources.

The database of the Italian Ministry of Education (MIUR) accounts for about 59,000 buildings, $70 \%$ of which were built in the absence of any legislation related to energy efficiency [2], and therefore they were built before 1976, when the first law on this topic was promulgated in Italy. Many buildings, due to aging or because of their poor construction quality, are in critical condition, and their energy systems are quite old and inefficient. Several international literature studies have reported complaints about poor comfort conditions in classrooms. Zomorodian et al. [3] showed that adequate levels of 
ventilation were fundamental to guarantee good indoor air quality in classrooms and that students' thermal preferences could not be in the comfort range provided by the standards. In addition, the necessity of glare reduction was observed by Michael and Heracleous [4], after the assessment of visual comfort in educational buildings located in Southern Europe. Since a comfortable environment increases concentration and learning [5], indoor comfort levels in school buildings, as well as their consequent energy performance, are of primary importance.

The energy consumption of schools is mainly related to heating and lighting of the spaces [6]; energy consumption also depends on functions that are integrated with the educational functions, for example, laboratories, canteens, gyms, sports equipment, and evening courses. In Italy, following the Legislative Decree 63/2013 [7], public buildings, with a total useful surface greater than $250 \mathrm{~m}^{2}$, must be equipped with an energy performance certificate. Therefore, several studies have been developed that defined energy consumption benchmark values for school buildings. For example, according to a study related to the Lazio region, the primary energy consumption of the regional school park was between 20 and $25 \mathrm{kWh} / \mathrm{m}^{3} \mathrm{a}$, depending on the time of construction [8]. Another study about the energy consumption of 29 schools located in central Italy was developed by Desideri and Proietti [9], and they reported that heating represented about the $80 \%$ of the total energy requirement and that the potential saving achievable through retrofitting was $38 \%$ for thermal energy and $46 \%$ for electricity. Another important collection of data about the energy consumption by space heating of 120 schools in the province of Turin, northwest of Italy, was collected by Corgnati et al. [10]. The sample was characterized by an average specific energy supply for space heating of $38 \mathrm{kWh} / \mathrm{m}^{3}$. A variable energy consumption was also found for a sample of 60 schools located in the province of Treviso, northeast of Italy, by Arambula Lara et al. [11], which reported normalized values that ranged from 0.53 to $8.41 \mathrm{Wh} /\left(\mathrm{m}^{3} \mathrm{Kh}\right)$.

The interventions that are usefully proposed mainly concern the reduction of heating energy requirement, for example, insulation of external walls, substitution of windows, an increase in the efficiency of the energy generators, installation of regulation systems, installation of shadings, and integration of renewable energy systems [12]. Butala and Novak [13] showed that the insulation of walls and substitution of windows were the most effective interventions from a cost and energy perspective for some Slovenian schools. Zinzi et al. [14] proposed a deep energy retrofit for Plauto School in Cesena (north Italy); the interventions regarded the insulation of envelope, replacement of windows, installation of condensing boilers, and installation of regulation and control systems (e.g., thermostatic valves and programmable thermostats). The energy saving observed after two years of monitoring was very high, i.e., space heating was cut from 143 to $23 \mathrm{kWh} / \mathrm{m}^{2}$ year $(-84 \%)$. De Santoli et al. [15] performed an economic analysis of some retrofit interventions in schools located in Lazio (central Italy) and considered the simple payback time as a useful parameter to identify priorities for action. Different combinations of interventions regarding envelope (e.g., insulation and substitution of windows) and energy systems (e.g., condensing boilers, thermostatic valves, etc.) were proposed. Ceccherini and Donato [16] performed an energy audit of three schools in Florence (central Italy) and quantified the energy savings in terms of a costs and benefits ratio, i.e., the simulated energy consumptions were compared with bill data obtained during the energy audit. Very interesting payback times were obtained by substituting fluorescent lamps with Light Emitting Diode (LED) lights (two to four years), while quite longer periods were calculated for the installation of insulation panels and thermostatic valves (11 years) and for replacement of windows (12-13 years also considering incentives). Dall' $\mathrm{O}^{\prime}$ and Sarto [17] showed that, although it was very important to upgrade schools through energy retrofitting, it was not always economically convenient to push energy performance beyond certain values and that environmental aspects should also be taken into account.

The analyses found in the literature have usually focused on the detection of economic convenient and energy efficient interventions. A multicriteria approach was proposed 
by Moazzen et al. [18] and used to choose different alternatives. They showed that the potential primary energy saving could reach about $60 \%$ and that the global cost saving could be over $40 \%$. A methodology to evaluate the cost-optimal level of some energy retrofits was also introduced by the Commission Delegated Regulation No. 244/2012 [19]. The work proposed by Asdrubali et al. [20] tried to extend the cost-optimal and energetic analysis to an environmental analysis using life cycle analysis (LCA) methodologies. The integration of the LCA methodology is fundamental for a comprehensive evaluation of the real environmental performance of retrofit interventions. Different retrofit interventions that can be undertaken, in fact, can cause a burden shifting from one life cycle stage to another reducing the benefits achieved during the operational phase. In low energy constructions, the embodied components can contribute significantly to the total life cycle impacts. Recently, Opher et al. [21] estimated an incidence of $69 \%$ for the embodied carbon of a building subjected to an energy retrofit designed to achieve net zero carbon emissions. Röck et al. [22] analyzed 238 case studies and observed a recent trend of an increase in the embodied carbon of new or retrofitted buildings; starting from $\sim 20 \%$ in existing standard constructions, the embodied carbon could reach a share of $\sim 50 \%$ in new advanced buildings, or surpass $90 \%$ of the total in extreme cases. As a consequence, integration of life cycle optimization methodologies has already been proposed by different authors [23-26].

This work fits into this line of research and, by employing a multidisciplinary approach, aims at evaluating the environmental (considering primary energy consumption and related greenhouse gas emissions) and economic performance of some energy retrofit interventions proposed for a school building built in the 1960s. An extension of the energetic analysis to an environmental analysis is performed through the application of the LCA method and considering the embodied energy and carbon of the building components used for the retrofit. Moreover, a comprehensive economic and financial analysis is performed that considers the financial discounting of monetary flows and employs a probabilistic approach to evaluate the sensitivity of the results to uncertain variables. The two analyses are undertaken separately, and then the results are compared.

The paper is organized as follows: In Section 2, we describe the materials and methodologies used for the energy, economic, and life cycle analysis; in Section 3, we introduce the case study; in Section 4, we report the results of the study; while in Section 5, we provide the conclusions.

\section{Materials and Methods}

The study was conceived as an integration of two main assessments, i.e., an environmental analysis that focused on the impacts linked to energy consumption and related greenhouse gas emissions, and an economic analysis.

\subsection{Energy Modeling and Life Cycle Indicators}

An accurate analysis of a building's energy retrofit options can be performed using simulation models that reproduce the thermal behavior of the structure. To build such models, a dynamic software such as TRNSYS (Transient System Simulation Tool, Thermal Energy System Specialists, Madison, WI, USA) can be used; the code is able to accurately reproduce both the external environmental conditions, through the "TRNSYS Studio" interface, and the geometry of the buildings, through the "TRNSYS Build" interface [27]. The software is based on an advanced calculation code, which applies the approach of the transfer function of Mitalas [28], and the implementation of specific types, or small program codes written in FORTRAN or $\mathrm{C}++$ language. The energy modeling of the case study building was performed in a dynamic hourly regime.

The following inputs were defined in the software: the location, the weather-climatic conditions, the plant components, the characteristics of the building envelope (both transparent and opaque), and the indoor air temperature set points. For the analyzed building, 11 thermal zones were identified, and the following were specified for each of them: 
- Operating data, i.e., the volume of air $\left(\mathrm{m}^{3}\right)$ and the total heat capacity of the air within the area, as well as the type of heating, infiltration, and humidity;

- Opaque surfaces (area in $\mathrm{m}^{2}$, orientation, materials, thicknesses, and thermophysical characteristics of the different masonry packages);

- Transparent surfaces (area in $\mathrm{m}^{2}$, orientation, thermal transmittance of the frame, and the type of different windows).

The building's characteristics were defined by visual inspections and in situ measurements, through the use of a heat flow meter, temperature probes, and a thermal imaging camera. The heat flow meter was used to estimate the thermal transmittance of the walls, the temperature probes were used to measure the temperature of the air inside the building, while the thermal imaging camera made it possible to analyze the building envelope, in order to assess heat losses.

These measurements were important for the calibration process of the building model, which took place in compliance with the admissibility ranges of the mean bias error (MBE) and coefficient of variation of the root mean square error (CV(RMSE)) indices [29], using the following equations, Equations (1) and (2):

$$
\begin{gathered}
\operatorname{MBE}(\%)=\frac{\sum_{i=1}^{N_{p}}\left(m_{i}-s_{i}\right)}{\sum_{i=1}^{n} m_{i}} \\
C V_{R M S E}(\%)=\frac{\sqrt{\sum_{i=1}^{N}\left(m_{i}-s_{i}\right)^{2} / N_{p}}}{\bar{m}}
\end{gathered}
$$

where $m_{i}$ and $s_{i}$ are, respectively, measured and simulated data values for each model instance $i ; N_{p}$ is the number of data points at interval $p$; and $\bar{m}$ is the average of the measured data values.

The model is considered to be calibrated if the MBE is between $\pm 10 \%$ and the CV(RMSE) range is $\pm 30 \%$, on an hourly basis, in accordance with the criteria established by the American Society of Heating, Refrigerating, and Air-Conditioning Engineers (ASHRAE) Guideline 14 [30,31].

Subsequently, the calibrated building energy model was used to simulate retrofit strategies aimed at reducing annual energy needs and improving the building thermal performance.

After that, the results obtained from the building energy modeling were employed as input for the LCA analysis, with the aim of determining the effectiveness of the proposed retrofits in terms of reduction in primary energy consumption and related greenhouse gas emissions.

The two main indicators to evaluate the environmental effectiveness of energy retrofit interventions are the energy payback time (EPBT) and the carbon payback time (CPBT). It is possible to define the energy payback time as the ratio between the variation of embodied energy (EE) of the building following the retrofit and the annual energy savings (ESa) achieved through the retrofit, as in Equation (3):

$$
E P B T=\frac{\Delta E E}{E S a}
$$

Similarly, the carbon payback time is defined as the ratio between the change in embodied carbon (EC) of the building following the retrofit and the annual emissions avoided (CSa) through the retrofit, as in Equation (4):

$$
C P B T=\frac{\triangle E C}{C S a}
$$

The calculation of the EE and EC variation of the building was carried out using the SimaPro software (Prè Sustainability, Amersfoort, The Netherlands): in particular, the Ecoinvent database was used and the single impact indicators called cumulative energy 
demand (CED) and global warming potential (GWP 100a) were employed. As shown in Figure 1, the embodied impacts were determined using a "cradle to site" approach that includes the stages A1-A4 defined in the product category rules for the compilation of the environmental product declarations of buildings [32].

\begin{tabular}{|c|c|c|c|c|c|c|c|c|c|c|c|c|c|c|c|}
\hline \multicolumn{3}{|c|}{$\begin{array}{l}\text { Production } \\
\text { stage }\end{array}$} & \multicolumn{2}{|c|}{$\begin{array}{c}\text { Construction } \\
\text { stage }\end{array}$} & \multicolumn{7}{|c|}{$\begin{array}{c}\text { Use } \\
\text { stage }\end{array}$} & \multicolumn{4}{|c|}{$\begin{array}{l}\text { End of life } \\
\text { stage }\end{array}$} \\
\hline A1 & $\mathrm{A} 2$ & $\mathrm{~A} 3$ & A4 & A5 & B1 & B2 & B3 & B4 & B5 & B6 & B7 & $\mathrm{C} 1$ & $\mathrm{C} 2$ & $\mathrm{C} 3$ & $\mathrm{C} 4$ \\
\hline 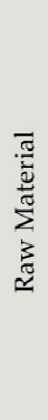 & 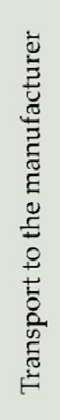 & 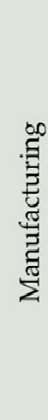 & 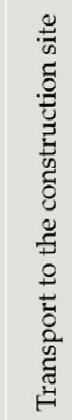 & 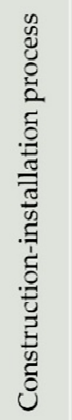 & $\stackrel{\sharp}{\sqcup}$ & 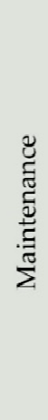 & 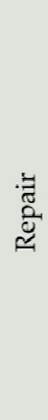 & 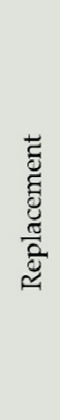 & 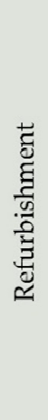 & 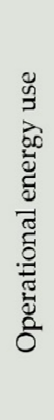 & 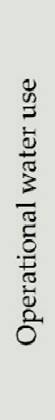 & 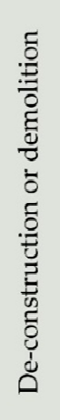 & 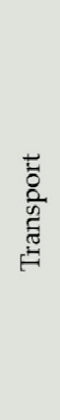 & 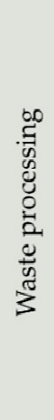 & 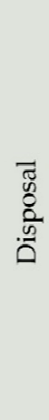 \\
\hline$\checkmark$ & $\checkmark$ & $\checkmark$ & $\checkmark$ & & & & & & & & & & $\checkmark$ & $\checkmark$ & $\checkmark$ \\
\hline
\end{tabular}

Figure 1. Life cycle stages considered for the calculation of the energy payback time (EPBT) and carbon payback time (CPBT) (green marked).

In the case of wooden materials, on the one hand, the biogenic carbon was not considered to be within the calculation of the CPBT. The energy consumption connected to phase A5, on the other hand, was considered to be negligible.

Phases B1-B5 have been neglected since, in general, the energy and carbon return times are much lower than the useful life of the different components [20]. As regards Stage B6, the most updated primary energy conversion and emission factors that referred to Italy were employed in the life cycle impact assessment phase.

The end-of-life is, instead, an essential part of a building's life cycle and different hypotheses can be made about the recycling or reuse potential of the materials and components. In this work, the adopted approach considered only stages $\mathrm{C} 2-\mathrm{C} 4$, neglecting any sort of benefit deriving from recycling or reusing of dismantled materials. In this way, the end-of-life of the components dismantled during a retrofit generates an increment of the environmental impacts linked to the retrofit intervention. As proposed for the construction and installation process, the deconstruction stage (C1) was considered to be negligible, since the operations did not need energy intensive processes. The entire building was considered to be a functional unit.

\subsection{Economic Analysis}

From an economic-financial perspective, the international literature seemed to estimate the convenience of retrofit interventions in an incomplete manner.

Mainly, it considered the energy savings, resulting from retrofit interventions, as the only economic benefit, choosing the intervention which guaranteed the quickest recovery of the investment or the shortest payback time (Verbeeck and Hens [33], Ballarini et al. [34], Niemela et al. [35], and Ortiz et al. [36]).

The suggested method was quite easy to apply, but it showed two factors of weakness:

- The method does not discount, with an appropriate cost of capital, the costs and benefits of the investment, which occur in different years, often in very long periods, and that are estimates (i.e., uncertain values);

- The method does not provide a threshold value, with which to compare the recovery period of individual interventions (for a stand-alone evaluation of their convenience). 
The analysis conducted here applied a complete financial approach, which only considered the monetary costs and benefits of the retrofit. The net present value (NPV) was used, which measured the today's monetary value of the intervention and it discounted the net cash flows by a rate which considered the time value of the money and the risk premium, calculated with reference to the main risk drivers of the investment. The retrofit is convenient if the NPV is non-negative and it is the more convenient the higher its value.

Furthermore, a probabilistic approach was used to measure the risk of the NPV of each retrofit alternative: it assumed optimistic and pessimistic estimates (defined in a subjective manner) of the uncertain variables and measured the corresponding range of NPV. This analysis provides two useful results for a decision maker:

- To identify which variable, that influences the investment's NPV, mostly affects its variability (sensitivity analysis);

- To derive an approximate measure of the risk of retrofit, under some hypotheses (Hull [37]); in fact, it is possible to estimate the probability distribution of the NPV that allows the decision maker to choose better than a single value; the decision maker can translate his/her risk aversion into a minimum acceptable percentage of non-negative values of the NPV and compare the percentage emerging from the NPV probability distribution with this threshold value (Berk et al. [38]).

However, as it usually happens in the literature, the economic-financial analysis conducted here considered only the energy savings of the retrofit which were measurable in monetary terms. It did not consider its environmental benefits (in this case lower $\mathrm{CO}_{2}$ emissions) and, generally speaking, its impact on the "internal environmental quality" (IEQ), due to the difficulty and subjectivity of their economic measurement, despite the cruciality of these aspects for educational buildings, due to their specific characteristics. A multicriteria methodology (MCDA) is being developed that would measure, for the different retrofit interventions, the main descriptors of the IEQ in relative terms, with respect to the acceptable ranges defined by EU regulations. This approach uses linear optimization models in order to allow the decision maker to compare the retrofit alternatives with each other and with the current state of a building.

\section{The Case Study}

The case study is represented by the Institute "Via Giuliano da Sangallo" in Ostia, near Rome (located in climatic zone D by the Italian law number 412 of 1993 [39]). The building, built in the 1960s, is characterized by an exposed steel structure and opaque infill panels, alternated with transparent surfaces (Figure 2), according to a very common typology at that time. The building is equipped with a conventional heating system with a natural gas boiler and radiators, while it has no summer cooling.

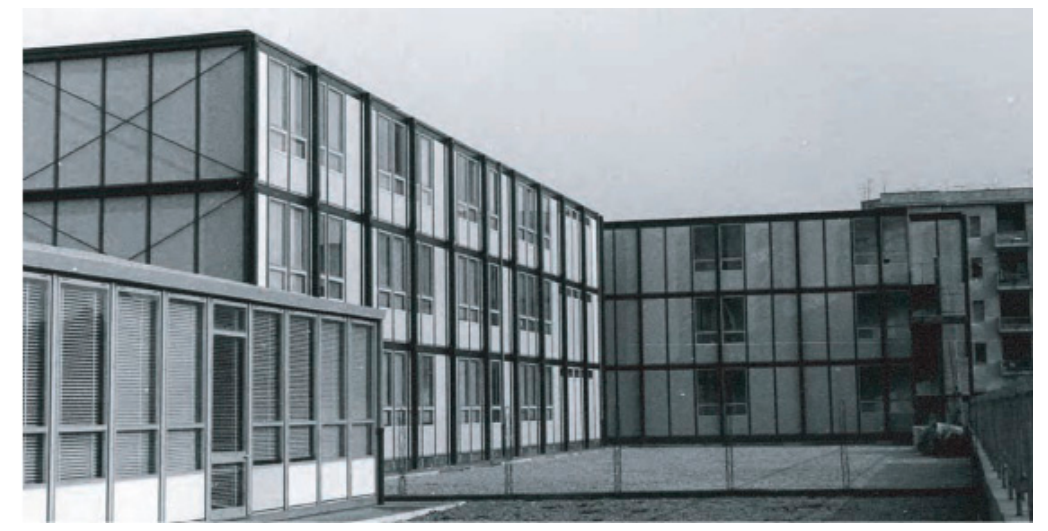

Figure 2. Picture of the school "Via Giuliano da Sangallo" in Ostia.

The school is characterized by a total glazed surface of $199 \mathrm{~m}^{2}$, with an iron frame and $4 \mathrm{~mm}$ single glass with a thermal transmittance of $5.10 \mathrm{~W} / \mathrm{m}^{2} \mathrm{~K}$. The window assumed for 
the retrofit is double glazed, has a thickness of $8 \mathrm{~cm}$ with a wooden frame and a "warm edge" plastic spacer. Two types of windows were proposed:

- $\quad$ Type 1 window, U-value $2.83 \mathrm{~W} / \mathrm{m}^{2} \mathrm{~K}$, g-value 0.755 , and T-vis 0.817 ;

- $\quad$ Type 2 window, U-value $2.54 \mathrm{~W} / \mathrm{m}^{2} \mathrm{~K}$, g-value 0.440 , and T-vis 0.472 .

Since it was not possible to obtain the original technical design reports or carry out in situ destructive investigations, the determination of the actual masonry package took place following an iterative process, i.e., different packages, all characterized by the presence of Eternit and foaming, were assumed and different thicknesses and thermophysical characteristics of the layers were hypothesized until the U-value (thermal transmittance) equal to $0.257 \mathrm{~W} / \mathrm{m}^{2} \mathrm{~K}$ was reached, which was within $20 \%$ of the maximum admissible tolerance as compared with the measured value, equal to $0.214 \mathrm{~W} / \mathrm{m}^{2} \mathrm{~K}$. The latter was determined thanks to the execution of measurements on a typical wall of the school, by means of a complete instrumentation, consisting of a thermofluximetric plate applied on the wall being analyzed and of internal and external air temperature probes. The installation of a thermal coat was proposed as a further retrofit intervention, according to the specifications reported in Table 1.

Table 1. Thickness and properties of the materials used for the insulation.

\begin{tabular}{ccc}
\hline External Insulation & Density & Thickness (cm) \\
\hline Insulation glue & $1500 \mathrm{~kg} / \mathrm{m}^{3}$ & 0.5 \\
XPS & $32 \mathrm{~kg} / \mathrm{m}^{3}$ & 5 \\
First leveling plaster & $2000 \mathrm{~kg} / \mathrm{m}^{3}$ & 1 \\
Fiberglass mesh $33 \times 33$ & $1 \mathrm{~kg} / \mathrm{m}^{2}$ & $\sim 0$ \\
Second leveling plaster & $2000 \mathrm{~kg} / \mathrm{m}^{3}$ & 1 \\
Insulation glue & $1500 \mathrm{~kg} / \mathrm{m}^{3}$ & 0.5 \\
\hline
\end{tabular}

The total surface area of the external masonry subjected to the installation of the coat is $500 \mathrm{~m}^{2}$. The insertion of the insulation reduces the thermal transmittance of the external walls down to $0.188 \mathrm{~W} / \mathrm{m}^{2} \mathrm{~K}$. This value is lower than the current legal limits in force in Italy [40], and therefore the insertion of a higher thickness is considered to be unnecessary. By combining the replacement of fixtures with external insulation, the following scenarios were hypothesized for the energy retrofit:

- $\quad$ Retrofit 1 , replacement of transparent surfaces with Type 1 windows

- Retrofit 2, replacement of transparent surfaces with Type 2 windows

- Retrofit 3, the same as Retrofit 1 plus a thermal coat with a thickness of $5 \mathrm{~cm}$

- Retrofit 4 , the same as Retrofit 2 plus a $5 \mathrm{~cm}$ thick thermal coat.

\section{Results}

\subsection{Energy and Environmental Aspects}

The energy model of the building was calibrated by comparing the internal air temperature values of a classroom, taken as a "control zone" and acquired through the in situ measurements, with those simulated by the software (Figure 3). 


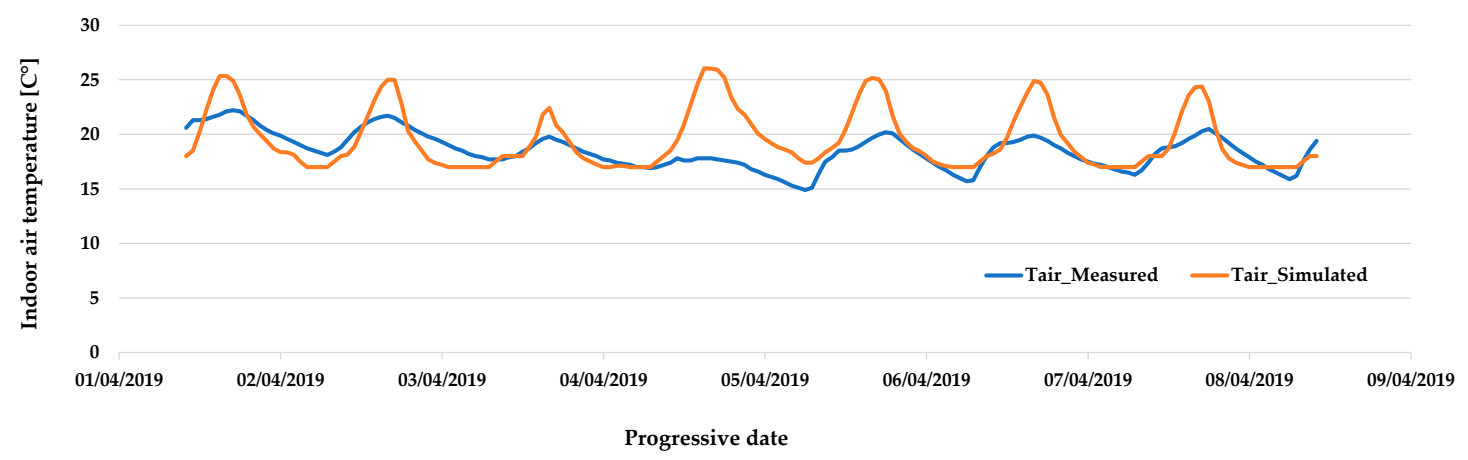

Figure 3. Comparison between measured and simulated indoor air temperatures.

In particular, the values of the MBE and CV(RMSE) indexes were equal to $-5.4 \%$ and $13.3 \%$, respectively, falling within the range identified by ASHRAE $( \pm 10 \%$ for the MBE and $\pm 30 \%$ for the CV(RMSE)).

The calibrated model was used to estimate the current heating needs of the building and the heating needs resulting from the different retrofit interventions (Figure 4).

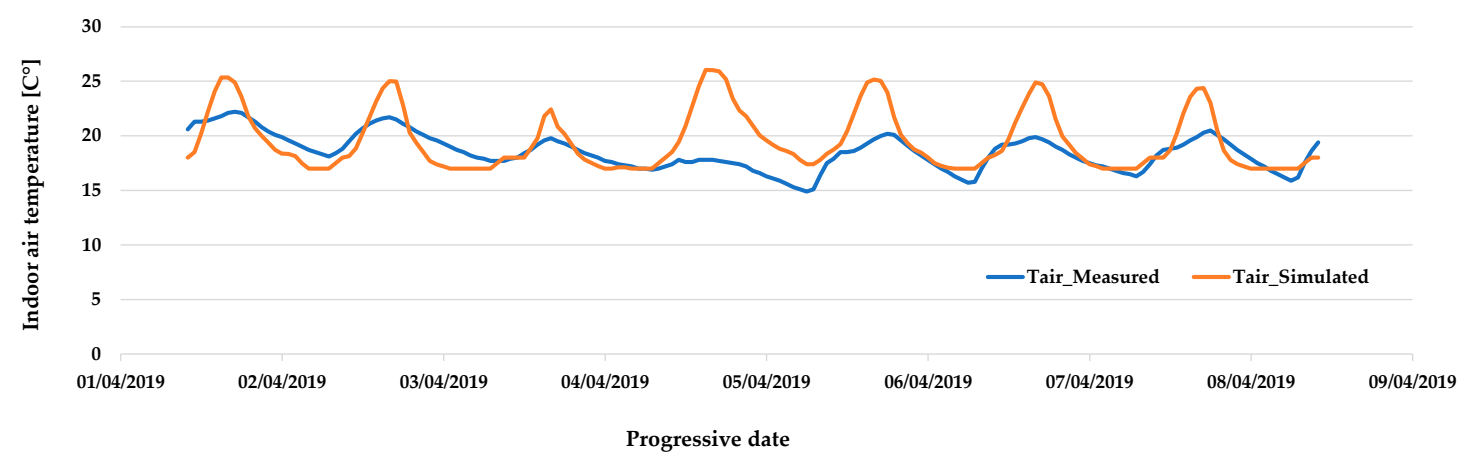

Figure 4. Annual consumption of primary energy for heating $(\mathrm{kWh} / \mathrm{y})$ of the various scenarios.

The most significant retrofit interventions in terms of decrease in annual primary energy consumption for heating are those offered by the replacement of fixtures (Retrofits 1 and 2), while the additional installation of the external coat in XPS has only a limited impact (Retrofit 3 and 4 ) because the perimeter walls already have quite a low thermal transmittance. Furthermore, the school under study is characterized by an overall transparent surface of $199 \mathrm{~m}^{2}$; therefore, an intervention on the high transparent component of the building envelope is a very effective retrofit solution.

Figure 5 shows the renewable and non-renewable parts of the CED for the various retrofit interventions.

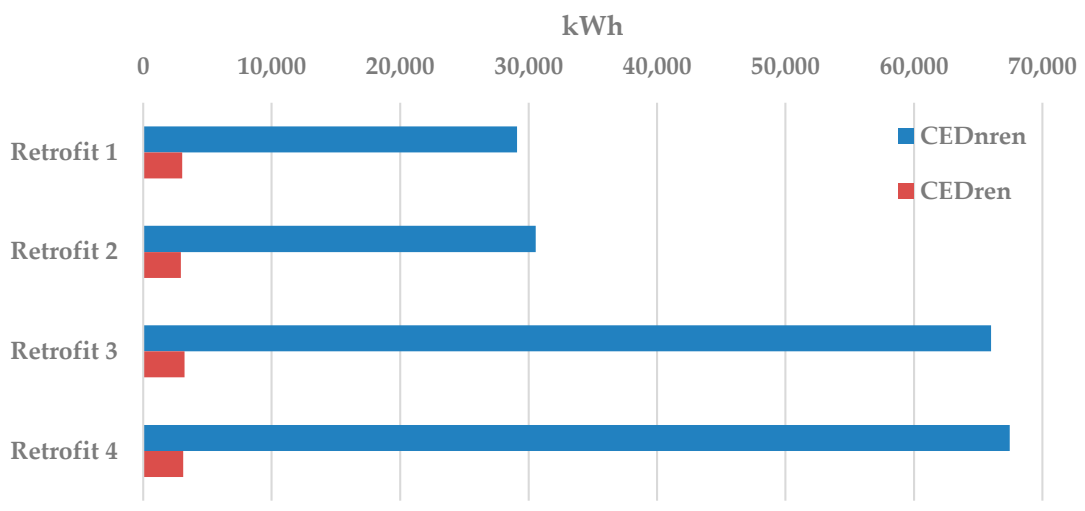

Figure 5. Cumulative energy demand (CED) for the various retrofits, i.e., renewable $\left(\mathrm{CED}_{\mathrm{ren}}\right)$ and non-renewable $\left(\mathrm{CED}_{\text {nren }}\right)$ values. 
As it can be noted, the retrofits add mainly non-renewable primary energy to the embodied energy of the building. The contribution of the impacts derived from dismantling the existing windows is about $2 \%$. The calculation results for the EPBT and CPBT values are shown in Table 2.

Table 2. Results related to energy and $\mathrm{CO}_{2}$ paybacks.

\begin{tabular}{|c|c|c|c|c|c|c|}
\hline $\begin{array}{l}\text { Retrofit } \\
\text { Option }\end{array}$ & $\begin{array}{c}\Delta \mathrm{EE} \\
(\mathrm{kWh})\end{array}$ & $\begin{array}{c}\Delta \mathrm{EC} \\
\left(\mathrm{kgCO}_{2} \mathrm{eq}\right)\end{array}$ & $\begin{array}{l}\text { Energy } \\
\text { Saving } \\
(\mathrm{kWh} / \mathrm{y})\end{array}$ & $\begin{array}{c}\text { Avoided } \\
\text { Emissions } \\
\left(\mathrm{kgCO}_{2} / \mathrm{y}\right)\end{array}$ & $\begin{array}{c}\text { EPBT } \\
\text { (Years) }\end{array}$ & $\begin{array}{l}\text { CPBT } \\
\text { (Years) }\end{array}$ \\
\hline Retrofit 1 & 32,124 & 8231 & 14,731 & 2961 & 2.18 & 2.78 \\
\hline Retrofit 2 & 33,472 & 8827 & 12,891 & 2591 & 2.60 & 3.41 \\
\hline Retrofit 3 & 69,217 & 16,651 & 15,054 & 3026 & 4.60 & 5.50 \\
\hline Retrofit 4 & 70,565 & 17,247 & 13,184 & 2650 & 5.35 & 6.51 \\
\hline
\end{tabular}

The various retrofits cause an increase in the embodied impacts which is only temporary, since the obtained energy and carbon paybacks, which are equal to about two to three years for the replacement of the fixtures and five to six years when the external coat is also added, are shorter than the useful life of the components. Furthermore, as confirmed by other literature studies [20], the energy and carbon return times are lower than the economic ones. However, it should be emphasized that the values obtained do not consider the additional impacts associated with phases B1-B3.

\subsection{Economic Aspects}

In order to calculate the NPV, the differential costs and benefits of the four analyzed retrofit interventions (as compared with the current state) were estimated.

Lazio Region's price list was used to estimate the material and processing costs necessary to insulate the walls and to replace the transparent surfaces. The costs of retrofit Interventions 1 and 2 also include, in addition to the supply of materials and glass windows with frames, the assembling/disassembling costs of the new/old fixtures and their installation. Interventions 3 and 4, in addition to the costs of Retrofits 1 and 2, include costs of the installation of the external thermal coat as follows: supply of insulating materials, plaster, painting of the surface, and assembling, for a total surface of $500 \mathrm{~m}^{2}$.

In order to estimate benefits, the annual savings related to the methane gas consumption and the tax incentives ex Decreto Interministeriale 16.02.2016 (called Conto Termico 2.0 [41]) were considered.

The price of methane gas was obtained by the average of prices applied by different suppliers in 2020, equal to 0.0985 euro per kWh. From the historical price series of methane gas over the last 10 years (Eurostat data) an annual growth rate of methane gas of $1.77 \%$ was obtained, applied during the whole duration of the retrofit (as a trend estimate).

As far as the duration is concerned, Choi et al. [42] showed that a useful life of 20 years is usually taken as a benchmark for insulating materials such as the XPS. However, the material may not be removed from the walls and it could continue to partially carry out its task for 20 years more. Therefore, for this kind of intervention, a linear compound decay rate was estimated to be equal to $1.575 \%$ per year from year 20 to year 40 . The windows guarantee the declared performance for 30 years on average; and then they gradually decay up to simply playing a role of separation between inside and outside, after a further 30 years (Litti et al. [43]). This means that, for the first 30 years, the new window performs an insulation function which complies with the values declared at the time of installation, i.e., from year 30 to year 60 , an annual compound decay rate has been estimated of $2.47 \%$ and of $2.84 \%$ for the retrofit Interventions 1 and 2, respectively.

To estimate the tax incentives, based on the current regulation, a tax deduction of $40 \%$ of the total expenditure was assumed over five years.

To estimate the cost of capital, the capital asset pricing model approach was used, with the following parameters: 
- $\quad$ Risk free rate equal to $1.59 \%$, obtained from the average of the 10-year BTP returns during the last 12 months (Investing data) (the rate includes both inflation expectations and country risk premium, perceived by the market);

- Market risk premium equal to 5\% (IBES consensus estimate);

- Beta equal to 0.65 , estimated on the basis of the systematic variability of the methane gas price (source, Eurostat), referred to the Italian GDP (sources, Bank of Italy and Istat) from 1991 to today. The 1991-2019 time series of Italian GDP and methane gas price are considered, obtaining variation coefficients (i.e., their normalized volatility) of $22.36 \%$ and $18.76 \%$, respectively; their Pearson coefficient of correlation is 0.77 . Beta was calculated using Equations (5) and (6) as follows:

$$
\begin{gathered}
\text { beta }=\frac{\text { correlation }_{\text {gas price, } G D P} \times \text { volatility }_{\text {gas price }}}{\text { volatility }_{G D P}} \\
\text { beta }=\frac{0.77 \times 0.1876}{0.2236} \cong 0.65
\end{gathered}
$$

A cost of capital of $4.84 \%$ was obtained by Equations (7) and (8) as follows:

$$
\begin{gathered}
\text { cost of capital }=\text { riskfree rate }+ \text { beta } \times \text { market risk premium } \\
\text { cost of capital }=1.59+0.65 \times 5=4.84
\end{gathered}
$$

and it was used as a discount rate of the energy savings.

The tax incentives were discounted by the risk-free interest rate, since they were relatively certain.

Table 3 summarizes costs, benefits, and NPV of the four retrofits.

Table 3. Calculation of the net present value (NPV) of retrofit interventions (euros).

\begin{tabular}{ccccc}
\hline Cash Flows and NPV & Retrofit $\mathbf{1}$ & Retrofit $\mathbf{2}$ & Retrofit $\mathbf{3}$ & Retrofit 4 \\
\hline Present value (energy savings) & $36,270.62$ & $31,427.93$ & $36,226.61$ & $31,468.96$ \\
Present value (tax deduction) & $20,094.95$ & $22,007.58$ & $34,252.11$ & $36,164.74$ \\
Lump-sum investment & $51,835.81$ & $56,769.52$ & $88,354.81$ & $93,288.52$ \\
NPV & 4529.76 & -3334.01 & $-17,876.09$ & $-25,654.83$ \\
\hline
\end{tabular}

It is possible to conclude that the only retrofit that gives economic benefits is the Retrofit 1, with a positive expected NPV. Retrofits 3 and 4, which foresee the application of the outside coat, have excessively high costs as compared with the energy savings they generate.

A sensitivity analysis was implemented for retrofit Interventions 1 and 2 (the only ones valuable on the basis of the results of the previous analysis), by forecasting optimistic and pessimistic estimates of the main uncertain drivers of the NPV, i.e., duration, methane price, and cost of capital. The assumptions were the following:

- The duration is included in the range of 55-65 years; the full saving range is 2535 years, and the decay period is a further 30 years.

- The methane gas price's change is equal to $\pm 13 \%$ (as compared with 2020), measured on the basis of the price semiannual time series (Eurostat data). The gas price is assumed to be normally distributed and the values corresponding to $5^{\circ}$ and $95^{\circ}$ percentiles of probability distribution are considered (this variation is added to the growth trend, hypothesized above).

- The cost of capital is included in the range $4.24-5.52 \%$, calculated as follows: (i) As an optimistic estimate, a risk-free rate equal to $1.59 \%$ and a beta of 0.53 are considered (the average beta of listed producers from Datastream dataset is used). (ii) As a pessimistic estimate, the average beta of the gas industry (but including both gas producers and related service providers) and a risk-free rate equal to $1.82 \%$ are used. In this case, the risk-free rate was measured by adopting a more conservative approach, in fact, 
the German Bund 10-year returns were corrected by means of the inflation differential between Germany and Italy and a country risk premium was added, by using the differentials of credit default swap (CDS) spreads over 10 years (Bloomberg data).

Table 4 shows the NPV values corresponding to the above estimates (changing a driver at a time) and the related NPV range.

Table 4. Sensitivity analysis of the NPV.

\begin{tabular}{ccccccccccc}
\hline & Input Data & & \multicolumn{2}{c}{$\begin{array}{c}\text { NPV (Optimistic } \\
\text { Estimate) }\end{array}$} & \multicolumn{2}{c}{$\begin{array}{c}\text { NPV (Pessimistic } \\
\text { Estimate) }\end{array}$} & \multicolumn{2}{c}{ NPV Range } & \multicolumn{2}{c}{$\begin{array}{c}\text { Coefficient of } \\
\text { Sensitivity }\end{array}$} \\
\hline $\begin{array}{c}\text { Uncertain } \\
\text { Drivers }\end{array}$ & $\begin{array}{c}\text { Optimistic } \\
\text { Estimate }\end{array}$ & $\begin{array}{c}\text { Pessimistic } \\
\text { Estimate }\end{array}$ & $\begin{array}{c}\text { Retrofit } \\
\mathbf{1}\end{array}$ & $\begin{array}{c}\text { Retrofit } \\
\mathbf{2}\end{array}$ & $\begin{array}{c}\text { Retrofit } \\
\mathbf{1}\end{array}$ & $\begin{array}{c}\text { Retrofit } \\
\mathbf{2}\end{array}$ & $\begin{array}{c}\text { Retrofit } \\
\mathbf{1}\end{array}$ & $\begin{array}{c}\text { Retrofit } \\
\mathbf{2}\end{array}$ & $\begin{array}{c}\text { Retrofit } \\
\mathbf{1}\end{array}$ & $\begin{array}{c}\text { Retrofit } \\
\mathbf{2}\end{array}$ \\
\hline $\begin{array}{c}\text { Duration } \\
\text { (years) }\end{array}$ & $35+30$ & $25+30$ & 6048.42 & -1961.9 & 2767.81 & -4925.93 & 3280.61 & 2964.02 & $6.1 \%$ & $6.7 \%$ \\
$\begin{array}{c}\text { Methane } \\
\text { price } \\
\text { (kwh) }\end{array}$ & 0.1113 & 0.0857 & 9244.94 & 751.62 & -185.42 & -7419.64 & 9430.36 & 8171.26 & $50.5 \%$ & $50.9 \%$ \\
$\begin{array}{c}\text { Cost of } \\
\text { capital }\end{array}$ & $4.24 \%$ & $5.52 \%$ & 9005.37 & 486.09 & 271.31 & -6978.21 & 8734.06 & 7464.30 & $43.3 \%$ & $42.4 \%$ \\
\hline
\end{tabular}

The last two columns measure the coefficients of NPV sensitivity, i.e., how much each driver variability influences the NPV variability.

Figure 6 shows the cumulative probability distribution of NPV of each retrofit, where NPV variance is measured as in Equation (9) (by simplifying, the uncertain drivers are assumed to be independent of each other and linearly related to NPV):

$$
\sigma_{N P V}^{2}=\sum k_{i}^{2} \times S_{i}^{2}
$$

where $S_{i}=\mathrm{NPV}$ range between optimistic estimate $U_{i}$ and pessimistic one $L_{i}$ of uncertain driver $i$ (see columns 8-9 in Table 4 ) and $k_{i}=\sigma_{i} /\left(U_{i}-L_{i}\right)$, where $\sigma_{i}$ is its volatility (in this case, $k_{i}$ is equal to 0.3$)$.

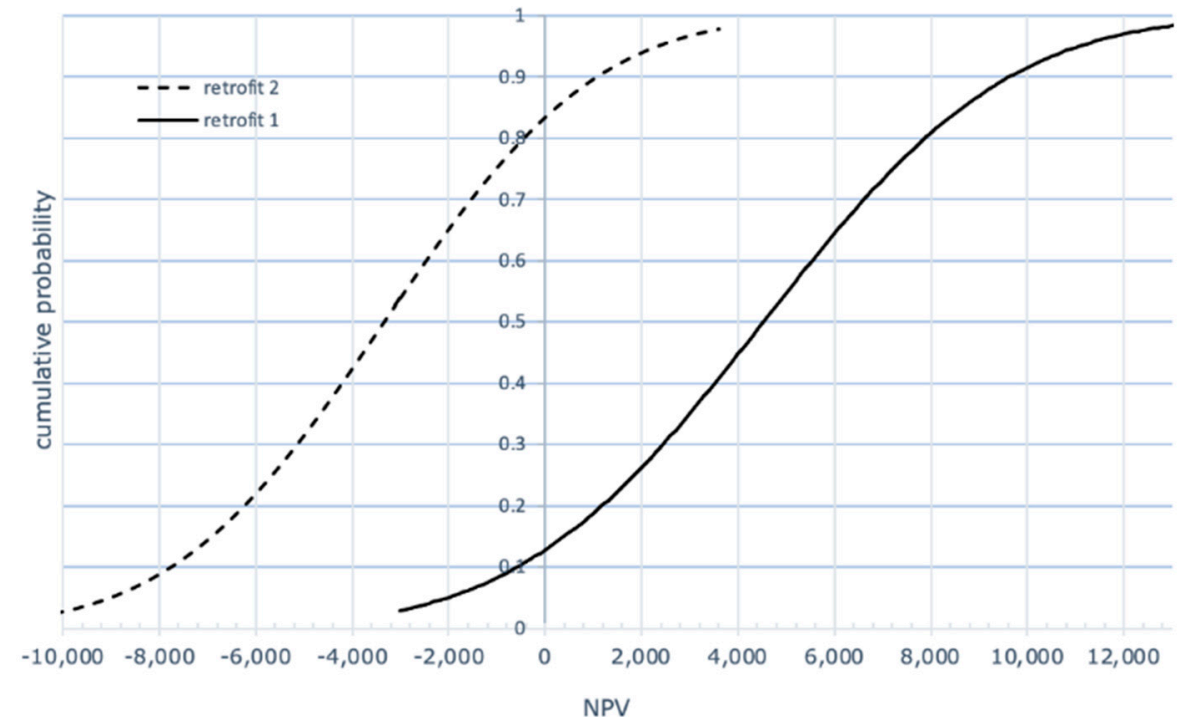

Figure 6. NPV cumulative probability distributions of Retrofits 1 and 2. 
The main results are the following:

- The NPV volatility mainly depends on the change of gas price, as well as the cost of capital (about 50\% and 43\%, respectively); on the contrary, the duration variability affects NPV dispersion less than $7 \%$.

- Retrofit 1 has a variation coefficient of NPV equal to $88 \%$ and the $90 \%$ of NPV distribution is in the range $-2000 /+11,000$ euros and assumes non-negative values in $87 \%$ of the cases. It is also a convenient investment, from a risk perspective. On the contrary, Retrofit 2 has a variation coefficient of NPV equal to $103 \%$, its NPV is in the range $-9000 /+2300$ euros (in $90 \%$ of the cases) and has non-negative values only in $17 \%$ of the cases.

\subsection{Limitations and Future Developments}

The obtained results are strongly dependent on the specific case study. The construction has a high transparent surface and a modular steel structure that is only characteristic of some buildings realized during the sixties. Therefore, the results obtained should not be generalized.

As regards the LCA, it should, in principle, include all relevant environmental impacts related to the analyzed product or service. The present study focuses only on energy resources consumption and climate change, neglecting other categories of environmental impact. Acidification, for example, can represent a significant environmental burden in the case of windows products [44]. The current standards [45] do not specify the impact categories that must be included in a LCA analysis but they only give some suggestions about typical environmental impacts. Future evaluations can be performed including other LCA impacts or aggregated indicators.

The results are also strongly sensitive to the hypothesis made about the lifetime of the materials proposed for the retrofit. Other authors have already underlined [46] the high sensitivity of LCA results to the proposed lifespan of the building studied.

Regarding the financial analysis, it includes only costs and benefits that are measurable in monetary terms, excluding the improvements in the IEQ and the environmental benefits deriving from the reduced greenhouse gas emissions and other environmental impacts. What is still difficult to determine is the impact of the retrofit on the learning capabilities and educational performances of the students. Therefore, the benefits achievable should embrace the improvements in internal comfort conditions and in educational performances. This field is still worth future research developments.

\section{Conclusions}

The existing building stock was built in Italy before the regulations on energy efficiency had a significantly high potential of energy saving. Existing public buildings, including schools, should adopt, in an exemplary way, the most advanced energy standards. The work presents the results of a study conducted on a school located in Ostia, near Rome, built in the 1960s. After carrying out on-site measurements to determine the current energy performance, four retrofit scenarios were simulated, i.e., two related to the replacement of fixtures and two characterized by an external coat. Then, an economicfinancial analysis was performed to determine the NPV of every intervention and its probability distribution. This approach guarantees the possibility of selecting the interventions with a positive NPV and also allows the decision maker to compare the NPV probability distribution with his/her risk aversion in terms of the minimum acceptable percentage of non-negative values that can be sustained. Finally, LCA methodologies are applied to calculate the energy and carbon payback times with the aim of integrating the economic-financial analysis with an environmental analysis.

The results show that the environmental convenience, from an energy consumption and climate change point of view, of only replacing the frames is higher than that of the combined interventions on windows and walls. The results also show that a windows replacement scenario (Retrofit 1 ) is the only scenario that has a positive NPV. This sce- 
nario represents the best solution from both economic and environmental perspectives, and therefore has strong relevance in the definition of the retrofit to be realized.

Author Contributions: Conceptualization, F.A. and D.V.; methodology, F.A., D.V., L.E. and C.G.; software, G.G. and M.R.; experimental investigation, L.E. and C.G.; LCA analysis, G.G.; economic analysis: P.M.; writing—original draft preparation, M.R., G.G. and P.M.; writing—review and editing, F.A. and D.V.; supervision, F.A. and D.V. All authors have read and agreed to the published version of the manuscript.

Funding: This research was carried out as part of the "Sustainibility of Schools-SoS" research project, funded by the Roma Tre University. The full name of project is "SoS—Sustainability of Schools. Definizione di tecnologie, metodologie e protocolli d'uso per salubrità, benessere e risparmio energetico nei luoghi di formazione" ("SoS—Sustainability of Schools. Definition of technologies, methodologies and protocols of use for health, well-being and energy saving in training places"), published in the "Extraordinary research development plan, Action 4, for experimental funding action for innovative and interdisciplinary research projects", and recipient of a research grant of $€ 64,000$.

Data Availability Statement: Data available on request due to restrictions. The data presented in this study are available on request from the corresponding author. The data are not publicly available due to privacy reasons.

Conflicts of Interest: The authors declare no conflict of interest.

\section{References}

1. European Parliament and Council. Directive 2010/31/EU of the European Parliament and of the Council of 19 May 2010 on the Energy Performance of Buildings; European Union: Brussels, Belgium, 2010.

2. Italian Ministry of Education (MIUR) List and localization of Educational Buildings. Available online: https://dati.istruzione.it/ opendata/ (accessed on 29 October 2020).

3. Zomorodian, Z.S.; Tahsildoost, M.; Hafezi, M. Thermal comfort in educational buildings: A review article. Renew. Sustain. Energy Rev. 2016, 59, 895-906. [CrossRef]

4. Michael, A.; Heracleous, C. Assessment of natural lighting performance and visual comfort of educational architecture in Southern Europe: The case of typical educational school premises in Cyprus. Energy Build. 2017, 140, 443-457. [CrossRef]

5. De Giuli, V.; Da Pos, O.; De Carli, M. Indoor environmental quality and pupil perception in Italian primary schools. Build. Environ. 2012, 56, 335-345. [CrossRef]

6. Pereira, L.D.; Raimondo, D.; Corgnati, S.P.; Da Silva, M.G. Energy consumption in schools-A review paper. Renew. Sustain. Energy Rev. 2014, 40, 911-922. [CrossRef]

7. President of Italian Republic Legislative Decree of 4 June 2013, n. 63 “Disposizioni urgenti per il recepimento della Direttiva 2010/31/UE del Parlamento europeo e del Consiglio del 19 maggio 2010, sulla prestazione energetica nell'edilizia per la definizione delle procedure d'infrazione avviate dalla Commissione europea, nonché altre disposizioni in materia di coesione sociale". Available online: https:/ / www.gazzettaufficiale.it/eli/id/2013/06/05/13G00107/sg (accessed on 29 October 2020).

8. Marrone, P.; Gori, P.; Asdrubali, F.; Evangelisti, L.; Calcagnini, L.; Grazieschi, G. Energy Benchmarking in Educational Buildings through Cluster Analysis of Energy Retrofitting. Energies 2018, 11, 649. [CrossRef]

9. Desideri, U.; Proietti, S. Analysis of energy consumption in the high schools of a province in central Italy. Energy Build. 2002, 34, 1003-1016. [CrossRef]

10. Corgnati, S.P.; Corrado, V.; Filippi, M. A method for heating consumption assessment in existing buildings: A field survey concerning 120 Italian schools. Energy Build. 2008, 40, 801-809. [CrossRef]

11. Lara, R.A.; Pernigotto, G.; Cappelletti, F.; Romagnoni, P.; Gasparella, A. Energy audit of schools by means of cluster analysis. Energy Build. 2015, 95, 160-171. [CrossRef]

12. Carbonari, A. Retrofit of Italian School Buildings. The Influence of Thermal Inertia and Solar Gains on Energy Demand and Comfort. Future Cities Environ. 2019, 5. [CrossRef]

13. Butala, V.; Novak, P. Energy consumption and potential energy savings in old school buildings. Energy Build. 1999, 29, 241-246. [CrossRef]

14. Zinzi, M.; Agnoli, S.; Battistini, G.; Bernabini, G. Deep energy retrofit of the T. M. Plauto School in Italy-A five years experience. Energy Build. 2016, 126, 239-251. [CrossRef] 
15. De Santoli, L.; Fraticelli, F.; Fornari, F.; Calice, C. Energy performance assessment and a retrofit strategies in public school buildings in Rome. Energy Build. 2014, 68, 196-202. [CrossRef]

16. Nelli, L.C.; Donato, A. Energy Auditor and Building Certification: Three School Buildings Case Studies in Florence, Italy. In Green Buildings and Renewable Energy; Sayigh, A., Ed.; Springer: Cham, Switzerland, 2020; pp. 589-599. [CrossRef]

17. Dall'O', G.; Sarto, L. Energy and Environmental Retrofit of Existing School Buildings: Potentials and Limits in the Large-Scale Planning. In Buildings for Education; Della Torre, S., Bocciarelli, M., Daglio, L., Neri, R., Eds.; Springer: Cham, Switzerland, 2019; pp. 317-326.

18. Moazzen, N.; Ashrafian, T.; Yilmaz, Z.; Karagüler, M.E. A multi-criteria approach to affordable energy-efficient retrofit of primary school buildings. Appl. Energy 2020, 268, 115046. [CrossRef]

19. European Commission. Commission Delegated Regulation (EU) No 244/2012 of 16 January 2012 Supplementing Directive 20102/31/EU; European Union: Brussels, Belgium, 2012.

20. Asdrubali, F.; Ballarini, I.; Corrado, V.; Evangelisti, L.; Grazieschi, G.; Guattari, C. Energy and environmental payback times for an NZEB retrofit. Build. Environ. 2019, 147, 461-472. [CrossRef]

21. Opher, T.; Duhamel, M.; Posen, I.D.; Panesar, D.K.; Brugmann, R.; Roy, A.; Zizzo, R.; Sequeira, L.; Anvari, A.; MacLean, H.L. Life cycle GHG assessment of a building restoration: Case study of a heritage industrial building in Toronto, Canada. J. Clean. Prod. 2021, 279, 123819. [CrossRef]

22. Röck, M.; Saade, M.R.M.; Balouktsi, M.; Rasmussen, F.N.; Birgisdottir, H.; Frischknecht, R.; Habert, G.; Lützkendorf, T.; Passer, A. Embodied GHG emissions of buildings-The hidden challenge for effective climate change mitigation. Appl. Energy 2020, 258, 114107. [CrossRef]

23. Grazieschi, G.; Gori, P.; Lombardi, L.; Asdrubali, F. Life cycle energy minimization of autonomous buildings. J. Build. Eng. 2020, 30, 101229. [CrossRef]

24. Asdrubali, F.; Baldassarri, C.; Fthenakis, V. Life cycle analysis in the construction sector: Guiding the optimization of conventional Italian buildings. Energy Build. 2013, 64, 73-89. [CrossRef]

25. Sharif, S.A.; Hammad, A. Simulation-Based Multi-Objective Optimization of institutional building renovation considering energy consumption, Life-Cycle Cost and Life-Cycle Assessment. J. Build. Eng. 2019, 21, 429-445. [CrossRef]

26. Sharif, S.A.; Hammad, A. Developing surrogate ANN for selecting near-optimal building energy renovation methods considering energy consumption, LCC and LCA. J. Build. Eng. 2019, 25, 100790. [CrossRef]

27. TRNSYS. Transient Systems Simulation Tool. Available online: http://www.trnsys.com (accessed on 3 December 2012).

28. Mitalas, G.P. Transfer function method of calculating cooling loads, heat extraction and space temperature. ASHRAE J. 1973, 14, 54-56. [CrossRef]

29. Lam, K.P.; Zhao, J.; Ydstie, E.B.; Wirick, J.; Qi, M.; Park, J.H. An EnergyPlus whole building energy model calibration method for office buildings using occupant behavior data mining and empirical data. In Proceedings of the 2014 ASHRAE/IBPSA-USA Building Simulation Conference, Atlanta, GA, USA, 10-12 September 2014; pp. 160-167.

30. Evangelisti, L.; Guattari, C.; Gori, P. Energy Retrofit Strategies for Residential Building Envelopes: An Italian Case Study of an Early-50s Building. Sustainability 2015, 7, 10445-10460. [CrossRef]

31. ANSI/ASHRAE. ASHRAE Guideline 14-2002 Measurement of Energy and Demand Savings; ASHRAE: Atlanta, GA, USA, 2002.

32. Wiklund, U. PCR 2014:02 Buildings (Version 2.0). Available online: https://www.environdec.com/PCR/Detail/?Pcr=5950 (accessed on 29 October 2020).

33. Verbeeck, G.; Hens, H. Energy savings in retrofitted dwellings: Economically viable? Energy Build. 2005, 37, 747-754. [CrossRef]

34. Ballarini, I.; Corrado, V.; Madonna, F.; Paduos, S.; Ravasio, F. Energy refurbishment of the Italian residential building stock: Energy and cost analysis through the application of the building typology. Energy Policy 2017, 105, 148-160. [CrossRef]

35. Niemelä, T.; Kosonen, R.; Jokisalo, J. Cost-effectiveness of energy performance renovation measures in Finnish brick apartment buildings. Energy Build. 2017, 137, 60-75. [CrossRef]

36. Ortiz, J.; Casas, A.F.I.; Salom, J.; Soriano, N.G.; I Casas, P.F. Cost-effective analysis for selecting energy efficiency measures for refurbishment of residential buildings in Catalonia. Energy Build. 2016, 128, 442-457. [CrossRef]

37. Hull, J.C. The Evaluation of Risk in Business Investment; Pergamon Press: New York, NY, USA, 1980.

38. Berk, J.; De Marzo, P.; Venanzi, D. Capital Budgeting; Pearson Paravia Bruno Mondadori: Milan, Italy, 2009.

39. President of Italian Republic Decree of 26 August 1993, n. 412 "Regolamento recante norme per la progettazione, l'installazione, l'esercizio e la manutenzione degli impianti termici degli edifici ai fini del contenimento dei consumi di energia". Available online: https:/ / www.gazzettaufficiale.it/eli/id/1993/10/14/093G0451/sg (accessed on 29 October 2020).

40. Italian Ministry of Economic Development Ministry Decree of 26 June 2015 "Applicazione delle metodologie di calcolo delle prestazioni energetiche e definizione delle prescrizioni e dei requisiti minimi degli edifici". Available online: https://www. gazzettaufficiale.it/eli/id/2015/07/15/15A05198/sg (accessed on 29 October 2020).

41. Italian Ministry of Economic Development Decree of 16 February 2016 “Aggiornamento della disciplina per l'incentivazione di interventi di piccole dimensioni per l'incremento dell'efficienza energetica e per la produzione di energia termica da fonti rinnovabili". Available online: https://www.gazzettaufficiale.it/eli/id/2016/03/02/16A01548/sg (accessed on 29 October 2020). 
42. Choi, H.-J.; Kang, J.-S.; Huh, J.-H. A Study on Variation of Thermal Characteristics of Insulation Materials for Buildings According to Actual Long-Term Annual Aging Variation. Int. J. Thermophys. 2018, 39, 2. [CrossRef]

43. Litti, G.; Audenaert, A.; Lavagna, M. Life cycle operating energy saving from windows retrofitting in heritage buildings accounting for technical performance decay. J. Build. Eng. 2018, 17, 135-153. [CrossRef]

44. Salazar, J. Eco-Efficient Construction and Building Materials; Woodhead Publishing: Oxford, UK, $2014 ;$ ISBN 9780857097675.

45. International Organization for Standardization. ISO EN 14040_Environmental Management_Life Cycle Assessment_Principles and Framework; International Organization for Standardization: Geneva, Switzerland, 2006.

46. Islam, H.; Jollands, M.; Setunge, S. Life cycle assessment and life cycle cost implication of residential buildings-A review. Renew. Sustain. Energy Rev. 2015, 42, 129-140. [CrossRef] 